\title{
Knowledge and attitude regarding obstetric ultrasound among pregnant women: a cross sectional study
}

\author{
Nivedita Krishnamoorthy ${ }^{1 *}$, Ananthi Kasinathan ${ }^{2}$
}

\author{
${ }^{1}$ Department of Obstetrics and Gynaecology, Sri Manakula Vinayagar Medical College and Hospital, \\ Kalitheerthalkuppam-605107, Puducherry, India \\ ${ }^{2}$ Indira Gandhi Medical College and Research Institute, Kathirkamam-605009, Puducherry, India
}

Received: 27 April 2016

Accepted: 02 June 2016

\section{*Correspondence: \\ Dr. Nivedita Krishnamoorthy, \\ E-mail: niveog91@yahoo.com}

Copyright: () the author(s), publisher and licensee Medip Academy. This is an open-access article distributed under the terms of the Creative Commons Attribution Non-Commercial License, which permits unrestricted non-commercial use, distribution, and reproduction in any medium, provided the original work is properly cited.

\begin{abstract}
Background: Ultrasound examination forms an integral part of antenatal care both in high risk and normal pregnancies. Even though it acts as a source of reassurance about the well-being of her baby and also a source of connecting with her baby in the antenatal period, for many pregnant mothers in India it is still only a tool for sex determination and its other major uses remain in the background. Fear regarding its safety and doubts about its necessity are also prevalent among pregnant women. The purpose of this study is to assess the knowledge of antenatal mothers regarding the uses of ultrasound during pregnancy and also to assess their attitude towards ultrasound.

Methods: This is a descriptive cross sectional study carried out in Sri Manakula Vinayagar medical college and hospital, Puducherry, India between the periods of April 2014 to July 2014. 300 pregnant women were selected by simple random sampling among patients attending the antenatal clinic for routine checkup irrespective of their parity. After obtaining informed consent, these women were given a predesigned, self-administered questionnaire in local language that had questions on socio demographic data, knowledge regarding use of ultrasound in pregnancy, attitude towards ultrasound, source of information about ultrasound and awareness regarding PNDT act. The data was entered in SPSS and analyzed using descriptive statistics.

Results: Although awareness regarding the indications for USG during pregnancy was found to be fairly good among the participants , $36 \%$ of the them assumed determination of sex in utero as an indication for ultrasound.88\% of them considered ultrasound as safe and $98 \%$ considered it essential. $26 \%$ of the pregnant women considered that sex determination was permissible by law. Most of them obtained information regarding ultrasound from health providers and the role of media was negligible.

Conclusions: Awareness regarding the uses of USG during pregnancy and attitude towards ultrasound was good but knowledge about recommendations of PNDT act was lacking in pregnant women and so every possible route particularly extensive media coverage can be used to create awareness regarding the recommendations of the PNDT act to the public.
\end{abstract}

Keywords: Knowledge, Attitude, Ultrasound, Pregnant women, PNDT act

\section{INTRODUCTION}

Ultrasound examination during pregnancy has become an integral part of antenatal care throughout the world. This technology is an important tool for the obstetricians, to reassure their patients regarding the well-being of their fetus in utero. In a clinician's point of view, it is particularly useful in the management of high risk pregnancies, but is also used routinely in low risk pregnancies for detection of congenital malformations in the fetus, to locate placenta, to assess the presentation of the baby and its well-being. For a pregnant mother, ultrasound is a source of connecting with her baby and there is a belief that it initiates bonding with the baby. ${ }^{1}$ 
Studies have shown that USG is responsible for maternalfetal attachment and also helps in reducing maternal anxiety. $^{2}$

With the wide availability of ultrasound, the expectation of the general public towards ultrasound has dramatically increased but the actual knowledge regarding its use and its limitations are lacking in them. For many expectant parents in India, ultrasound is only a tool for sex determination. In spite of media coverage, the knowledge regarding PNDT act among antenatal women in studies from Rajasthan and Mumbai were found to be only $52.4 \%$ and $34.3 \%$ of their study population. ${ }^{3,4}$

Being a technology that is widely available, doubts' regarding its safety and usefulness is still persistent in antenatal mothers. The purpose of this study is to evaluate the knowledge of antenatal mothers regarding the uses of ultrasound during pregnancy and also to assess their attitude towards ultrasound.

\section{METHODS}

This is a descriptive cross sectional study carried out in Sri Manakula Vinayagar Medical College and Hospital, Puducherry, India between the period of April 2014 to July 2014 to assess the knowledge and attitude regarding uses of ultrasound in pregnant mothers. 300 pregnant women were selected by simple random sampling among patients attending the antenatal clinic for routine checkup irrespective of their parity. After explaining the purpose of the study and after obtaining informed consent, these women were given a predesigned, self-administered questionnaire in local language.

The questionnaire contained details of socio-demographic data and questions to assess knowledge and attitude regarding ultrasound in pregnant mothers. The knowledge part included 9 questions in the yes or no format to assess their knowledge of indications for ultrasound use during pregnancy. Attitude regarding ultrasound was assessed using questions which included questions on safety, its importance and the comfort level during USG examination using the Likert scale. ${ }^{4}$ Questions regarding their source of information and ideal number of scans formed the fourth part of the questionnaire. Awareness regarding PNDT act was assessed by asking them if they considered sex determination by ultrasound to be permissible by law. The date was entered in SPSS and analyzed using descriptive statistics. Institutional ethics committee approval was obtained for the study.

\section{RESULTS}

Among the 300 participants, 83\% were between 20-30 years and almost $99 \%$ of the study group has had formal education. $51 \%$ of the study group were primigravid women and $49 \%$ were multiparous. $33 \%$ of the participants have already had exposure to ultrasound for reasons other than pregnancy.

Table 1: Socio demographic data of participants.

\begin{tabular}{|llc|}
\hline Age & No & $\%$ \\
\hline$<20$ & 15 & 5 \\
\hline $20-30$ & 249 & 83 \\
\hline$>30$ & 36 & 12 \\
\hline Parity & \multicolumn{1}{c|}{} \\
\hline Illiterate & 3 & $1 \%$ \\
\hline School education & 171 & $57 \%$ \\
\hline Graduate & 126 & $42 \%$ \\
\hline Occupation & & \\
\hline Working & 96 & 32 \\
\hline Homemaker & 204 & 68 \\
\hline Parity & & 51 \\
\hline Primi & 153 & 49 \\
\hline Multi & 147 & 33 \\
\hline Exposure to USG & for reasons other than pregnancy \\
\hline Yes & 99 & 67 \\
\hline No & 201 & \\
\hline
\end{tabular}

Awareness regarding the indications for USG during pregnancy was found to be fairly good among the participant which is evident in Table 2 . But $36 \%$ of the participants assumed determination of sex in utero as an indication for USG during pregnancy which shows their ignorance of the PNDT act.

Table 2: Knowledge of pregnant women regarding uses of ultrasound.

\begin{tabular}{|lllll|}
\hline & Nes & & No & \\
\hline & No of ultrasound & No & $\%$ \\
\hline $\begin{array}{l}\text { To detect defects in the } \\
\text { baby }\end{array}$ & 210 & 70 & 90 & 30 \\
\hline To find the fetal position & 222 & 74 & 78 & 26 \\
\hline $\begin{array}{l}\text { To find the expected date } \\
\text { of delivery }\end{array}$ & 258 & 86 & 42 & 14 \\
\hline $\begin{array}{l}\text { To determine the sex of the } \\
\text { baby }\end{array}$ & 108 & 36 & 192 & 64 \\
\hline $\begin{array}{l}\text { To determine the position } \\
\text { of cord and placenta }\end{array}$ & 201 & 67 & 99 & 33 \\
\hline $\begin{array}{l}\text { To assess growth of the } \\
\text { baby }\end{array}$ & 264 & 88 & 36 & 12 \\
\hline To confirm pregnancy & 258 & 86 & 42 & 14 \\
\hline $\begin{array}{l}\text { To confirm presence of } \\
\text { multiple pregnancy }\end{array}$ & 237 & 79 & 63 & 21 \\
\hline $\begin{array}{l}\text { To confirm well-being of } \\
\text { the fetus }\end{array}$ & 267 & 89 & 33 & 11 \\
\hline
\end{tabular}

Almost $98 \%$ of the participants agreed that USG in an essential investigation during pregnancy but only $88 \%$ agreed that it was absolutely safe. $24 \%$ of the participants were uncomfortable during the examination. The communication of the findings of USG examination was not considered adequate by $19 \%$ of the participants. 
Table 3: Attitude towards ultrasound during pregnancy.

\begin{tabular}{|lcccc|c|c|}
\hline & Agree & \multicolumn{3}{c|}{$\begin{array}{c}\text { Neither } \\
\text { agree nor } \\
\text { Attitude }\end{array}$} & Disagree \\
\hline & No & \% & No & \% & No & $\%$ \\
\hline $\begin{array}{l}\text { Ultrasound is safe } \\
\text { during Pregnancy }\end{array}$ & 264 & 88 & 12 & 4 & 24 & 8 \\
\hline $\begin{array}{l}\text { Ultrasound in an } \\
\text { essential } \\
\text { investigation }\end{array}$ & 294 & 98 & 6 & 2 & - & - \\
during pregnancy & & & & & & \\
\hline $\begin{array}{l}\text { I felt comfortable } \\
\text { during ultrasound } \\
\text { examination }\end{array}$ & 246 & 82 & 30 & 10 & 24 & 8 \\
\hline $\begin{array}{l}\text { I was given details } \\
\text { of my baby by the } \\
\text { doctor who }\end{array}$ & 243 & 81 & - & - & 57 & 19 \\
performed the scan & & & & & & \\
\hline
\end{tabular}

Table 4: Source of information and awareness of PNDT act.

\begin{tabular}{|c|c|c|}
\hline \multicolumn{3}{|c|}{ Ultrasound advised by } \\
\hline & No & $\%$ \\
\hline Doctor & 261 & 87 \\
\hline Nurse & 18 & 6 \\
\hline Husband & 12 & 4 \\
\hline Friends & 9 & 3 \\
\hline \multicolumn{3}{|c|}{ Information regarding USG from } \\
\hline Doctors & 264 & 88 \\
\hline Nurse & 12 & 4 \\
\hline Friends/relatives & 18 & 6 \\
\hline Media & 4 & 2 \\
\hline \multicolumn{3}{|c|}{$\begin{array}{l}\text { Number of USG you consider is as ideal during } \\
\text { pregnancy }\end{array}$} \\
\hline 1 & 12 & 4 \\
\hline 2 & 60 & 20 \\
\hline 3 & 138 & 46 \\
\hline 4 & 45 & 15 \\
\hline$>4$ & 45 & 15 \\
\hline \multicolumn{3}{|c|}{$\begin{array}{l}\text { Do you think sex determination is permissible by } \\
\text { law? }\end{array}$} \\
\hline Yes & 78 & 26 \\
\hline No & 222 & 74 \\
\hline
\end{tabular}

Ultrasound was advised by the treating Obstetricians in $87 \%$ and $88 \%$ obtained information regarding ultrasound only from their doctors. Information obtained through media regarding ultrasound was negligible in the study. Regarding the ideal number of ultrasound during pregnancy $46 \%$ of the participants had considered that at least 3 scans were necessary.

When asked indirectly regarding the legal aspect of sex determination by ultrasound $26 \%$ had said that sex determination was permissible by law which shows that more awareness to be created regarding the PNDT act.

\section{DISCUSSION}

The awareness regarding the uses of ultrasound during pregnancy was fairly good among our participants. $88 \%$ of our subjects considered monitoring growth of the baby were the main indication for the ultrasound which is consistent with other studies. In a study by Munim et al, $82.1 \%$ considered monitoring growth as the main use, whereas only $51.9 \%$ of their study subjects considered USG as a tool to rule out structural malformations as compared to $70 \%$ of our participants. ${ }^{5}$ Similar studies by Wahabi et al from Saudi Arabia and Eniyandunni et al from Lagos, Nigeria have shown that only $19.8 \%$ and $17.5 \%$ of their participants were aware that ultrasound was used to rule out structural malformation. ${ }^{6,7}$

In our study $36 \%$ of the participants considered sex determination as an indication for ultrasound during pregnancy and $26 \%$ of them considered that sex determination was permissible by law. This shows their lack of awareness regarding the components of PNDT act. In their study on knowledge and attitude of pregnant mother regarding PNDT act carried out in a teaching hospital in Mumbai, the authors had shown that $34.3 \%$ their study subjects were aware of PNDT act and $77.1 \%$ of them considered that sex determination was a crime. ${ }^{4}$ A study from Rajasthan showed that the overall knowledge about PNDT act was present among 52.4\% of their participants. ${ }^{3}$

Doubts' regarding safety of ultrasound is persisting in all societies. Studies have shown that patients considered that too many ultrasound may be harmful to the baby and also had belief that ultrasound could cause cancer. ${ }^{8}$ In a qualitative study from Tanzania, many women believed that ultrasound could cause significant impairment to the mothers or their babies. ${ }^{9}$ But in our study we found that $88 \%$ of the participants considered ultrasound as safe and $82 \%$ of them claimed to have been comfortable during the examination. ${ }^{7}$

In our study $98 \%$ of the subjects, considered ultrasound as an essential component of antenatal care. Similar attitude was found in other studies from Pakistan and Ghana in which $93.5 \%$ and $95.3 \%$ considering ultrasound as an important investigation during pregnancy. ${ }^{5,10}$ In a study from Nigeria by Ikeako et al $73.1 \%$ of their subjects considered ultrasound as a routine test done for every pregnant woman. ${ }^{11}$

As compared to a study on Ghanian woman in whom $70.9 \%$ had complained that the sonographer did not communicate to them during and after the procedure only $19 \%$ of our participants felt that the person performing the ultrasound did not effectively communicate with them. ${ }^{10}$ 
Information regarding ultrasound was received from their treating doctors by $88 \%$ of our participants and only $2 \%$ received their information from the media. The above findings show that media coverage regarding judicious usage of ultrasound and particularly regarding sex determination and PNDT act is lacking.

\section{CONCLUSION}

In this study, the awareness regarding ultrasound use during pregnancy is fairly good. But in a socio-cultural background with a preference to a male baby, ultrasound is being used as a tool for sex determination followed by sex selective abortions in spite of strict regulations by the government. So every possible route should be used to create awareness regarding the recommendations of the PNDT act among the public.

\section{Funding: No funding sources}

Conflict of interest: None declared

Ethical approval: The study was approved by the Institutional Ethics Committee

\section{REFERENCES}

1. Enakpene CA, Morhason-Bello IO, Marinho AO, Adedokun BO, Kalejaiye AO, Sogo K, et al. Clients reasons for prenatal ultrasonography in Ibadan, South west of Nigeria. BMC Women's Health. 2009;9:12.

2. Boukydis CF, Treadwell MC, Delaney-Black V, Boyes K, King M, Robinson T, et al. Women's responses to ultrasound examinations during routine screens in an Obstetric clinic. J ultrasound Med. 2006;25(6):721-8.

3. Khatri M, Acharya R, Sharma G. Knowledge attitude and practices related to preconception and prenatal diagnostic techniques Act among the antenatal women in Bikaner. Scientific Reports. 2012;1:121.
4. Shidaye PR, Giri PA, Nagaonkar SN, Shidaye RR. Study of knowledge and attitude regarding prenatal diagnostic techniques act among the pregnant women at a tertiary care teaching hospital in Mumbai. J Edu Health Promot. 2012;1:36.

5. Munim S, Khawaja NA, Quereshi R. Knowledge and awareness of pregnant women about ultrasound scanning and prenatal diagnosis. J Pak Med Assoc. 2004;54:553-5.

6. Wahabi HA, Channa NA, Fayed A, Esmaeil SA, Masha ARO, et al. Knowledge, expectations and source of information of pregnant Saudi women undergoing second trimester ultrasound examination. Gynecol Obstet. (Sunnyvale). 2014;4:243.

7. Eniyandunni F, Soyebi K, Irurhe N, Olowoyeye O, Adeyomoye A, Ketiku K, Arogundade R. A survey of psychological reaction and perception of pregnant women, to prenatal ultrasonograpy in Lagos University teaching Hospital, Idi-Araba, Lagos. The Internet Journal of Health. 2010;13(1):1-9.

8. Oche OM, Umar AS, Raji MO, Kaoje AV, Godwin G, Ango JT, et al. Knowledge of the uses and indications for Obstetric ultrasound scan among women attending a main referral Hospital, Sokoto, Nigeria. Research in Obstetrics and Gynecology. 2013:2(5):55-62.

9. Firth ER, Mlay P, Walker R, Sill PR. Pregnant women's beliefs, expectations and experiences of antenatal ultrasound in Northern Tanzania. African Journal of reproductive health. 2011;15(2);91-107.

10. Mensah YB, Nkyekyer K, Mensah K. The Ghanian woman's experience and perception of ultrasound use in antenatal care. Ghana medical journal. 2014 8;48(1):31-8.

11. Ikeako LC, Ezegwui HO, Onwudiwe E, Enwereji JO. Attitude of expectant mothers on the use of ultrasound in pregnancy in a tertiary institution in South east of Nigeria. Ann Med Health Sci Res. 2014;4:949-53.

Cite this article as: Krishnamoorthy N, Kasinathan A. Knowledge and attitude regarding obstetric ultrasound among pregnant women: a cross sectional study. Int J Reprod Contracept Obstet Gynecol 2016;5:2192-5. 